\title{
Sentencing Ashley Smith: How Prison Conditions Relate to the Aims of Punishment
}

Lisa Kerr

\begin{abstract}
Ashley Smith's experience in the adult prison system flowed from certain of its systemic features. This article considers whether and how it is possible to reconcile the basic commitments of sentencing law, including the legal aims of punishment, with that systemic portrait. The youth court that ordered Smith's transfer to adult custody relied upon an idealized conception of adult imprisonment, just as ordinary adult sentencing courts do. Judges purport to stipulate the severity of punishment, but tend not to consider how prison conditions will shape the severity of the sanction. Even where a particular defendant is likely to face unique difficulties in custody, courts tend to take notice in limited and rare ways. Smith's experience in adult custody challenges us to more clearly identify, and to consider extending, doctrinal sentencing rules that represent a judicial concern with the effects and prospects of imprisonment in particular cases.
\end{abstract}

Keywords: Ashley Smith, sentencing, prison law, segregation, solitary confinement, punishment, theory

\section{Résumé}

L'expérience vécue par Ashley Smith dans le système carcéral pour adultes témoigne de certaines caractéristiques de ce système. Le présent article tente d'établir, d'une part, s'il est possible d'harmoniser les engagements de base des lois régissant la détermination de la peine, y compris les visées légales des sanctions, au système carcéral et, d'autre part, comment arriver à une telle harmonisation entre ces lois et la réalité de ce système. Le tribunal de la jeunesse qui a ordonné le transfert d'Ashley Smith dans un établissement correctionnel pour adultes a eu recours à une conception idéalisée de la détention des adultes, une conception partagée par les tribunaux pour adultes. Les juges prétendent stipuler la sévérité de la peine sans toutefois tenir compte du fait que les conditions de détention accroissent la sévérité de la sanction. Même si un accusé est susceptible d’éprouver des difficultés particulières durant sa détention, les tribunaux ont peu tendance à le remarquer ou à en tenir compte. Lexpérience de détention d'Ashley Smith dans un établissement correctionnel pour adultes lance le défi d'identifier plus précisément, voire d'élargir, la doctrine en matière de détermination de la peine témoignant d'une préoccupation judiciaire pour les effets de la détention dans certains cas particuliers.

Mots clés : Ashley Smith, peine, droit carcéral, ségrégation, isolement, punition, théorie

Canadian Journal of Law and Society / Revue Canadienne Droit et Société, 2017,

Volume 32, no. 2, pp. 187-207. doi:10.1017/cls.2017.14 
Sentencing judges are tasked with the job of imposing fit sanctions on those found guilty of crimes. Where the judge imposes a term of incarceration, the severity of the sanction is, formally speaking, established by its length. In the case of Ashley Smith, the practical severity of her punishment unfolded far from the judicial eye, for reasons almost wholly unrelated to the determination of her guilt for particular offences. In this respect, she was like any other inmate. While sentencing judges purport to hunt for and select a fit sanction in response to a particular level of blameworthiness, it is the penal administrative context that determines the qualitative terms of incarceration and ultimately the form and severity of state sanctions.

Smith was incarcerated almost continuously from the age of fifteen until her death, at age nineteen, on October 7, 2007. As a result of a youth court decision, Smith was transferred to an adult provincial jail at the age of eighteen, and then to a federal penitentiary once she had accrued additional custodial time. At the time of her death, Smith had been held for almost a year in highly punitive conditions of administrative segregation, despite multiple vulnerabilities, her young age and a criminal record that included only minor in-community offences. In 2013, the Office of the Chief Coroner of Ontario concluded that Smith's death was a homicide, which occurred because correctional officers followed a standing order from senior officials not to intervene while she tied ligatures around her neck and slowly suffocated. ${ }^{1}$

Like many of the decisions made in the course of her confinement, that final policy of non-intervention was shaped by managerial concerns rather than Ashley Smith's specific needs. ${ }^{2}$ At a preliminary inquiry concerning the criminal liability of these officers, one correctional officer described the orders they had received not to intervene. She said: "I was told by one manager that I was not to enter the cell; that I was there to observe her; it was going to test me but I needed to stay strong and just watch. I was told by another manager that I would not be entering the cell; at one point he actually stopped us from entering the cell."’ This same officer explained that officers were told not to enter the cell so as to reduce use of force reports: they were told that "we were not supposed to go in; that use of force was too high; we had too many incidents of use of force." Improving prison statistics took precedence over inmate care. Smith's management had regressed to the binary options of force or abandonment.

The facts of Smith's troubling case and needless death are now well known and have been chronicled and analyzed in several governmental reports, court decisions, a coroner's inquest, and excellent academic writing including that in this collection. Public and scholarly investigations reacting to the Smith case have

1 Chief Coroner of Ontario (2013), Inquest: Touching the Death of Ashley Smith: Jury Verdict and Recommendations.

2 Correctional Investigator of Canada, A Preventable Death (Ottawa: Office of the Correctional Investigator, 2008).

3 Evidence of Melissa Mueller, Preliminary Inquiry, November 27, 2008, at 38 1.5-39 1.26, cited in the Smith Family Factum in a civil trial motion, at p. 6, available online: http://www.falconers.ca/ wp-content/uploads/2015/07/Smith-Civil-Family-Factum.pdf.

4 Ibid. 
focused largely on the character of the Canadian prison system and the resistance of the federal prison service to oversight and reform, particularly with respect to the practice of placing prisoners with serious health problems in isolated segregation. These valuable studies have revealed a great deal about the correctional context itself-the place where we find the key practices, policies, and decisions that so severely impacted and ultimately ended Smith's life.

In this article, I turn away from the correctional context in order to consider the implications of the Smith case to the law and theory of sentencing. The idea is to analyze the underlying theories, applicable legal doctrine, and actual workings of our sentencing regimes in the light of the features of state punishment that were unveiled by the Smith case.

Scholars have not directly grappled with the sentencing consequences of this case, though many have expressed dismay at the minor, youth misconduct that brought Smith into the adult prison system in the first place. For example, the following passage observes how Smith's punishment was profoundly disconnected from the juridical concerns that likely underpinned her initial sentence: "Few could have imagined that a fifteen-year-old girl who received a one-month youth custodial sentence in the province of New Brunswick after breaching probation for leaving her parents' property and throwing crab apples at a postal worker, would be found dead four years later in a maximum-security federal prison segregation unit, while staff stood by and watched."

I want to focus on precisely this disconnect between the wrongdoing that brought Ashley Smith into custody, the reasons that underpinned decisions made in her case, and her experience in confinement.

In Smith's case, it was a transfer mechanism in the youth system, rather than a Criminal Code sentencing decision, that caused her placement in adult custody. The question I wish to examine is how her experience in adult custody should bear upon adult sentencing jurisprudence. ${ }^{6}$ I aim to connect our concerns with prison conditions and the administration of punishment to the task faced by judges at sentencing.

I analyze the Smith experience in adult custody from two angles. The first angle considers the penal theories that are thought—at least by scholars working in the field of punishment theory-to justify state punishment. Theories of state punishment circulate in philosophy journals and inform sentencing policy. I examine a selection of prominent theories to see whether and how they shed normative light on the Smith experience of confinement.

The second angle examines applicable sentencing law. I look at how practical and doctrinal issues related to mental health, prison conditions, and programming are dealt with-or neglected-in our sentencing courts.

Part I considers the implications of the Smith experience in custody for punishment theory. These are the normative theories that are thought to frame our

Nicole LeBlanc, Jennifer Kilty, and Sylvie Frigon, "Examining the preventable but predictable death of Ashley Smith," International Journal of Prisoner Health 11, no. 3 (2015): 126-40.

6 Another worthy topic, which I don't address here, is the relationship between Smith's custodial experience and the distinct sentencing jurisprudence of the Youth Criminal Justice Act, S.C. 2002 c.1. 
sentencing laws and supply the moral and political principles that are meant to guide the decisions and policies of legislatures, courts, and the prison system itself. One current, fashionable view expounds a notion of punishment as an expression of the censure that society needs and that offenders deserve. Another prevalent theory emphasizes the need for punishment to deliver retributive sanctions to deserving offenders.

Retributive and expressive theories of punishment are not abstract or academic topics for the Canadian legal system. Rather, these are theories that are at least partly endorsed in our Criminal Code. An expressive theory of punishment appears in the provision that punishment should "denounce unlawful conduct and the harm done to victims or to the community that is caused by unlawful conduct." Retribution or just deserts is explicitly present in the Code's commitment to proportionality, in the provision that punishment "must be proportionate to the gravity of the offence and the degree of responsibility of the offender." ${ }^{8}$ Given that these theories of punishment circulate in real ways in our legal system, it is worth asking whether and how these theories speak to how punishment is delivered on the ground.

Specifically, the Smith case challenges us to ask how a commitment to denunciation can be achieved when the administration of punishment occurs out of public view and in circumstances far removed from the commission of offences. Views that justify or explain punishment by pointing to its expressive values seem woefully disconnected from the basic features of today's prison system, where sentences are administered in secretive, closed institutions. We must also ask whether the legal commitment to proportionality is little more than window dressing when, as the Smith case so starkly demonstrates, the features of sentence administration are not tethered to the criminal records of inmates.

Part II is more practical and directly doctrinal. I ask what Smith's experience ought to mean for the legal issues that must be decided every day in our sentencing courts. I ask how facts about prison quality and concerns about sentence administration-like the trend of reliance on indefinite segregation as a means to address health, resource, and management problems-does or should impact how judges make sentencing decisions. This is particularly significant at a time when widely endorsed reform recommendations arising out of Smith's death have been refused by a recalcitrant federal prison service. ${ }^{9}$ While there have been amendments to segregation policies, these changes amount to tinkering. ${ }^{10}$ The prison

Criminal Code s. 718.

Criminal Code s. 718.1.

The federal government and Correctional Service Canada (CSC) have consistently refused to implement nonpartisan recommended limits on segregation, including most recently in "Response to the Coroner's Inquest Touching the Death of Ashley Smith" (Ottawa: Correctional Service of Canada, December 2014).

10 See e.g. the revised CSC Commissioner's Directive 709, 2015-10-13, which improves procedural protections for segregated inmates and contemplates the right to an "advocate" for mentally ill inmates in segregation. In sum, the policy is explicit that CSC continues to house mentally ill inmates in segregation, notwithstanding the Coroner's Inquest recommendation that this practice be prohibited. No time limits appear in the revised policy, notwithstanding the Coroner's Inquest recommendation to impose a limit of fifteen consecutive days in segregation and sixty cumulative days in a calendar year. 
service refuses to implement the two reforms that would create concrete limits on the use of segregation: a prohibition on the segregation of mentally ill prisoners, and time limits on the use of segregation in all cases. Rather than a unique tragedy or the outcome of a series of contingent, misguided decisions, Ashley Smith's death is a predictable outcome of the current legislative regime that governs the administration of segregation in federal penitentiaries. ${ }^{11}$ The situation has not changed and we ought to consider how to press sentencing courts to face these facts when imposing a sanction of imprisonment.

Part II shows how Canadian sentencing courts do address concerns about prison conditions in a number of important ways, but that this currently happens in a fashion that is inconsistent, ad hoc, and highly individualized in terms of both offender and judge. I identify and analyze two categories of cases. First, there are vulnerable defendant cases, in which sentencing courts respond to concerns about the impact of imprisonment on those with disabilities and particular health needs. Second, there are place of imprisonment cases, in which sentencing courts allow conditions of confinement to affect the judicial choice between a federal or provincial institution, provided that a proper evidentiary basis is put forward. Both categories of cases make clear that judges do hear evidence, in at least some cases, about how the defendants before them are likely to experience imprisonment. This part of the article aims to collect and identify the principles at work in these cases, which may help to regularize and entrench these approaches.

Lawyers, judges, wardens, and even scholars often treat the criminal courts and the penal administrative realm as two separate worlds. The punishment theorists that I discuss in Part I think that state punishment can be defined and even justified without considering the basic facts of how it will be delivered. The sentencing courts of Part II are only rarely pressed to consider how the severity of the sanctions they impose will be shaped by the traits of defendants and prison conditions. The Smith case cries out for the dissolution of these cognitive and legal boundaries. Ashley Smith's prison sentence was administered in ways that defied any sensible view of her criminal blameworthiness, and her subsequent in-custody offences were closely connected to her institutional struggles. The reforms that this case calls for must include those responsible for announcing custodial punishment, particularly given the legal and moral terms that those punishments are founded on.

\section{Background: The Youth Court Transfer Decision}

Smith's original confinement arose out of involvement in the youth criminal justice system for minor offences. On October 21, 2003, while on probation in relation to other charges, she left her family's yard and threw fruit at a postal worker. She then cycled in and out of youth custody, accruing new charges while awaiting sentencing on others. Her offences in the community were almost classically juvenile: pulling a fire alarm in a public building, stealing a CD from a local store. Most of her misconduct occurred in custody, where she clearly struggled to

11 See e.g. Lisa Kerr, "The Chronic Failure to Control Prisoner Isolation in US and Canadian Law," Queen's Law Journal 40, no. 2 (2015): 483-530. 
adjust to institutional life. ${ }^{12}$ Smith amassed a daily record of incidents that ranged from acting disruptively to refusing staff directives. Her stay in youth custody also included 150 documented instances of self-harm over a span of three years. Restraints and segregation were used throughout, with no apparent effect in terms of positive behavioural change. ${ }^{13}$

Eventually, Smith's record triggered a controversial application to move her from the youth system to adult custody. The move was effected by way of transfer provisions and a court hearing brought under s. 92 of the Youth Criminal Justice Act. ${ }^{14}$ Transfer to the adult system is automatic under this statute when a youth turns twenty, but this application was made when Smith was just eighteen. In accordance with the statute, the application was initiated by the director of the youth authority and was to be governed by analysis of Smith's best interests. Smith vigorously resisted the prospect of a transfer, citing fears of the adult system.

Following a hearing, a youth court judge granted the transfer. The New Brunswick Ombudsman and Child and Youth Advocate, Bernard Richard, describes the evidence that appeared to convince the court to grant the application: "In his decision to grant the section 92 application, the presiding judge gave considerable weight to the testimony given by two witnesses-Ashley's Probation officer and the Deputy Superintendent of the Saint John Regional Correctional Centre. During examination, these witnesses outlined the variety of programs available for women at the provincial adult correctional institution. These included programs provided by non-governmental organizations and focused mainly on self-esteem, anger management, relationships and substance abuse." ${ }^{\text {"15 }}$

In sum, the government led convincing evidence at this hearing about the programs available in the adult system. But Richard points out what was missing from both the evidence and the court's analysis:

12 For much of her institutional behaviour, Smith faced additional prosecutions in the ordinary criminal courts, and these proceedings substantially lengthened her initial sentence. In this way, the penal administrative context determines the quality of punishment but can also add to its temporal quantity. Invariably, offences committed in custody have a different factual matrix from those committed in the community - an assault committed on a passer-by in the town square is different than one committed against a trained correctional officer amid the stresses of incarceration-but inmates are often still held fully responsible for their in-custody actions in our criminal courts. Indeed, Renee Acoby was declared a dangerous offender based almost entirely on a record of in-custody behaviour. The Ontario Court of Appeal was entirely untroubled by the question of whether in-prison conduct is an appropriate indicator of the prospect that an individual is a risk to the community at large: R. $v$ Acoby, 2015 ONCA 75.

13 For a detailed discussion of her treatment and experiences in youth custody, see Office of the Ombudsman and Child and Youth Advocate Province of New Brunswick, "Ashley Smith: A Report of the New Brunswick Ombudsman and Child and Youth Advocate on the services provided to a youth involved in the youth criminal justice system," (June 2008), 7-27.

Youth Criminal Justice Act, s. 92: "(1) When a young person is committed to custody under paragraph 42(2)(n), (o), (q) or (r), the youth justice court may, on application of the provincial director made at any time after the young person attains the age of eighteen years, after giving the young person, the provincial director and representatives of the provincial correctional system an opportunity to be heard, authorize the provincial director to direct that the young person, subject to subsection (3), serve the remainder of the youth sentence in a provincial correctional facility for adults, if the court considers it to be in the best interests of the young person or in the public interest."

15 New Brunswick Ombudsman, supra at 26. 
The description of the information based programs was sufficiently appealing to have the Court conclude that a transfer to the SJRCC may very well serve this young person's best interests. What failed to be elucidated during the hearing was that in order to benefit from the programs offered to women at the SJRCC as described by the witnesses, a female offender has to present an "appropriate behaviour" to be entitled to these privileges. In any event, after weighing the arguments put forward before him, on October 5, 2006, the youth court judge granted the application. $^{16}$

As Richard astutely observes, the youth court judge relied upon the promise of enhanced programs in the adult system, but failed to canvas the likelihood that Smith would ever gain access to these programs. Equally significant is the fact that the youth court had no jurisdiction to see any promises about the adult system through-once Smith was transferred, that was the end of youth court involvement. In sum, the youth court made a decision that was formally framed by the best interests of Ashley Smith, but did so on the basis of facts that were both inadequately explored and inevitably speculative. Just as the youth court accepted thin evidence regarding the prospects of adult custody, so too do our everyday adult sentencing courts rely upon a conception of punishment that, while unavoidably prospective, is often idealized.

\section{Part I: The Smith Experience and Punishment Theory}

Sentencing theories like denunciation and just deserts emanate from the field of punishment philosophy, which is a branch of political philosophy that tries to identify the legitimate aims or grounds for state punishment. These theories do not have mere scholarly significance. They are reproduced in our Criminal Code and embedded in our sentencing jurisprudence. Lawyers and judges draw from them in concrete ways in arguing for and deciding punishment in specific cases.

In this part, I first consider how theories grounded on the moral educative aims of punishment relate to the custodial experience of inmates like Smith. My central foil in this first part is the punishment theorist Antony Duff, who identifies the communication of censure as the legitimate purpose of state punishment. A second foil will be the sociologist Emile Durkheim. While moral philosophers like Duff are focused on the legitimate purposes of punishment, Durkheim was focused on the social, moral and educative functions of punishment.

I chose these two thinkers because of the field-defining prominence of their work in philosophical and sociological theories of punishment. And I chose them because of the tangible presence of the basic outlines of their views in our courts and prisons today, even if the names Duff and Durkheim are not known or mentioned. Both of these views fail, in important ways, to account for the features of imprisonment in the Smith case study.

16 New Brunswick Ombudsman, supra at 27. 


\section{Fit Punishment to Express Censure}

Expressive schools of punishment theory argue that state punishment is legitimate where it communicates the censure or disapproval that offenders deserve. ${ }^{17}$ Antony Duff is a central figure in this school of thought, and his influential claim is that punishment should communicate to offenders that they are blameworthy on account of their crimes. A failure to punish in the face of wrongdoing "casts doubt upon the sincerity of my declaration that such conduct is seriously wrong." although the extent of the sanction must be constrained by what the offender deserves.

Consequential concerns are present in Duff too, as he envisions punishment as an expressive exchange with socially productive possibilities. Punishment must aim to persuade offenders to repent, to try to reform themselves, and thus to reconcile themselves with those whom they wronged. ${ }^{19}$ Punishment properly carries a message of blame, but must also respect the offender as a moral agent who can receive and respond to the message.

The implications of Duff's theory for substantive criminal law and sentencing theory are significant, and include that targets of state punishment must be able to understand, internalize, and respond to the communication that inheres in state punishment. But Duff's work tells us little about what these commitments mean in the practical, contemporary realm of prison administration. Engaged in a project of ideal theory, Duff does not explain what state punishment as a productive expressive exchange means for a practice of holding adults in locked penal facilities, largely isolated from public and even legal oversight.

A similar ambiguity appears in the work of Joel Feinberg, another key author in the tradition of expressivist justifications for punishment. Feinberg posits that criminal punishment is a unique vehicle for the expression of community values, with a symbolic significance largely missing from other kinds of penalties. ${ }^{20}$ The problem is that the symbolism of punishment is abstract, whether the practical punishment is a fine, confinement, or corporal punishment. As one Feinberg critic puts it, "there is no 'natural' representation that flows from "losing money, years of liberty, or parts of one's body.".21

These theories raise more questions than answers for those concerned with prison administration. How is it that punishment in the form of imprisonment carries moral messages? Do prison programs and policies communicate to offenders the fact of their blameworthiness in a way that invites them to repent? Do sentencing courts contemplate these questions as they rely on the discourse of expressive justifications when imposing punishment? In the Smith case, these rational

17 R. A. Duff, Trials and Punishments (Cambridge: Cambridge University Press, 1985); Jean Hampton, "The Moral Education Theory of Punishment," Philosophy and Public Affairs 13 (1984): 208-38; Andrew von Hirsch, Past or Future Crimes (New Brunswick, New Jersey: Rutgers University Press, 1985).

18 Duff at 28

19 Duff at xvii.

20 Joel Feinberg, "The Expressive Function of Punishment," The Monist 49, no. 4 (1965): 400.

21 A. J. Skillen, "How to Say Things with Walls," Philosophy 55, no. 214 (1980): 517. 
accounts of the expressive function of state punishment fall far short of accounting for or justifying her prison experience.

In reply to that critique, an expressive punishment theorist (or a sentencing judge) might simply agree, and might vigorously affirm that the Smith case represents violation rather than adherence to an acceptable normative framework of punishment. And yet, Smith's experience was possible because of systemic features of the prison system rather than an idiosyncratic, individual factor. Her experience was possible because of structural, institutional features common to contemporary prisons: including the radically unspecific character of a judicial decision to imprison combined with the vast discretion granted to prison officials, their power to control and isolate prisoners, and their authority to determine prisoner access to basic amenities and activities. A theory of punishment that legitimizes the use of imprisonment is, in some significant sense, condoning a system of state sanction with these features.

Another reply might be to say that punishment communicates condemnation through the length of the custodial sentence that is imposed, rather than through the conditions of confinement that follow. That reply might add: punishment theory actually demands uniformity in the administration of prisons and the lived experience of prisoners, such that the length of a sentence will truly be the lever of severity. One problem with this reply is that it denies the experience of the moral agent at the heart of the theory. The prisoner will likely point to her prison experience as a highly significant dimension of her punishment, rather than only to the minutes or hours that she appeared before the sentencing judge and the number of days or years that those proceedings generated.

A more significant problem with that position is that uniformity in the form and effect of imprisonment is an impossible stipulation. In fact, prison officials would argue strenuously that uniformity is antithetical to the task of prison management, which requires constant assessment and adjustment in light of resources, risk, and changing inmate profiles. Uniformity in sentence administration was certainly not achieved for Ashley Smith, nor was it even among the goals of those who handled her.

\section{Punishment to Sustain Collective Morality}

The sociologist Emile Durkheim did not work in the vein of 'justifications for punishment' like Duff or Feinberg, but he identified the necessity of punishment to serve similar purposes of expressing censure and thereby preserving community bonds and social order. At its core, Durkheim's view was that criminal punishment is the means by which society sustains solidarity. For Durkheim, a failure to punish violations of social morality undermines the collective force of that morality and runs the risk of demoralizing citizens. While crime is conceptualized as corroding the moral fabric of a society, punishment is thought to re-establish consensus about shared values. ${ }^{22}$ At the heart of Durkheim's work is a view that punishment is not simply an instrument of crime control: "it is also a sign that the

22 Emile Durkheim, The Division of Labour in Society (New York: The Free Press, 1984). 
authorities are in control, that crime is an aberration, and that the conventions which govern social life retain their force and vitality." ${ }^{23}$

Durkheim advanced the powerful view that state punishment will always be linked to the larger condition and needs of the society. He describes two kinds of social solidarity and argued that the intensity of punishment would depend on which mode was predominant in a particular setting. Mechanical solidarity describes a society where beliefs and sentiments are common to all the members of the group, where "the individual personality is absorbed in the collective personality." 24 Mechanical solidarity is most likely to characterize a "primitive" society, or one at an early developmental stage. Here, punishment will be more repressive, as the society depends on a completely shared social code, or what Durkheim called the conscience collective. ${ }^{25}$

The second type, organic solidarity, will characterize more "advanced" societies, which for Durkheim means those that are marked by the division of labour. In this setting, individuals are very different from one another but social cohesion persists because they rely on one another to perform distinct spheres of specialized work. Under conditions of organic solidarity, individuals have distinct skills and experiences but remain dependent upon one another. Durkheim thought punishment would be more moderate in these conditions. Strict protection of the collective consciousness would not be required given high levels of interdependence.

Durkheim also thought that the substantive law would serve as an index of the shared values of that society, and that the most important of these shared values would be protected by criminal law. While the substance of criminal prohibitions would vary across societies, every act deemed to be a crime would be an action understood by that social order to break the bonds of social solidarity, to disturb "emotions and dispositions strongly rooted within us." 26 The purpose of punishment, then, is to correct the disturbance caused by a break in our shared commitments. Punishment for a criminal offence serves to express and affirm the shared sentiments of the moral community whose values have been attacked by the wrongdoing. We can see in Durkheim a fully fleshed out theory that could underpin the commitment to denunciation in s. 718 of the Criminal Code.

In a revival of the significance of Durkheim's analysis of criminal law and punishment, David Garland raises several critiques which can be fruitfully transported for analysis of the legitimacy of the punishment administered on Ashley Smith. Perhaps most significantly, Garland argues that the emotional and psychological context within which punishment occurs is a "complex and ambivalent field of forces, rather than the uniform collective passion which [Durkheim] implies." ${ }^{27}$ The Smith case implores us to consider exactly what common values are generated or affirmed through the hidden processes of imprisonment.

Ibid.

Durkheim, 85.

Durkheim, 38-39.

Durkheim, 37.

David Garland, Punishment and Modern Society: A Study in Social Theory (Chicago, University of Chicago Press, 1990), 66. 
Garland points out that penal rituals do not just 'express' emotions, they also create them: "they arouse them and organize their content; they provide a kind of didactic theatre through which the onlooker is taught what to feel, how to react, which sentiments are called for in that situation." 28 The punishment teaches what is wrong, rather than merely expressing the pre-existing sentiments of a clear and stable moral order.

The administration of imprisonment can create categories of wrongdoing in the course of responding to such categories. As prison lawyers know: disciplinary problems for clients can flow from factors like cell assignment, security classification, institutional placement, programming access, staffing, and levels of tension and crowding in a facility. The punishment does not just communicate the fact of wrongdoing. Once we bring the details of prison administration into the picture, we can see how the methods of punishment generate new instances of wrongdoing. Inmates can be set up to fail by prison conditions like extreme isolation or a lack of meaningful healthcare. Additional sanctions against the resulting poor behaviour appear justified. Correctional officers rotating through their shifts cannot be expected to resist punitive treatment plans that appear to be responsive to that poor behaviour.

Punishment does more than simply express a clear repudiation of past conduct. For Ashley Smith, her institutional experiences slowly but effectively transformed her from a struggling youth to a deviant prisoner. The use of restraints, segregation, and forced medication in both youth and adult custody-and her upsetting responses to that treatment-had the effect of solidifying her status as the most difficult of prisoners. While throwing fruit as a child does not merit the harshest punishment, the actions of prison officials become more justified as we learn of her astonishing record of in-custody behaviour and as we witness visuals of her seemingly strange and self-injurious behaviour in segregated cells.

A further question is when, exactly, the public communication that is meant to inhere in criminal punishment actually occurs. Garland points out that Durkheim presumes that the criminal trial, the passing of sentence, and the execution of punishment will each play a part, that each will deliver the "formalized embodiment and enactment of the conscience collective." ${ }^{29}$ But historical perspective sheds a different light on that presumption. The turn to imprisonment as the predominant sanction for serious criminal offences changes what is possible in terms of the enactment of punishment and its possible effects on the wider social order. In the past, the ritual of punishment was often a public process, where the actual administration of the court's sanction could plausibly be thought of as the expression of, and attempt to confirm and regenerate, a public moral sensibility. Critically, the audience was present in the town square to absorb the message. Today, only the "declaration of punishment, rather than the process of punishment itself," is the "focus of public attention and the locus of ritual display." Sentencing courts

28 Ibid., 67. In other words, punishment is a "social occasion which simultaneously structures individual sentiment and gives it cathartic release" (68).

29 Ibid., 71.

30 Ibid., 71-72: “The penal process of modern societies has become a fragmented, differentiated sequence of events, in which certain aspects are subjected to close public scrutiny and involvement, and others are left to the management of professionals who, for the most part, maintain a low visibility and control their own information output" (71). 
might send an offender to prison on the basis of the need for public censure, but it is the internal processes of punishment that determine the sanction-to which the public is rarely privy.

Add to this that prison administrators and correctional officers do not consider their task to be the delivery of moral messages to inmates. In fact, prison officials tend to represent their operations in "neutral, technical terms" and to adopt a "managerial posture rather than a moral one." 31 Prison officials today tend to prefer to do their work without oversight and away from public view, and they tend to focus on security and calm operations rather than ambitious goals of psychological or moral transformation within offenders, much less the perceptions of the wider public. Conveying public sentiment is in fact antithetical to the formal goals and policies of the prison: "Institutional staff see themselves not as moral condemners but as impartial managers, committed to unemotive conduct and bureaucratic regimes." ${ }^{32}$ The point is that prisons are unlikely places for the expression of public sentiment, both because the focus of staff lies elsewhere and because there is little public engagement with the inner workings of these institutions.

Finally, Durkheim assumes that there is a moral community to which the offender must become more deeply bonded through the criminal justice experience. Garland points to the unlikely prospect that punishment will serve as a mechanism of moral reform in modern societies, where the moral community is often fragmented or absent, particularly for the chronically marginalized criminal offender who "lives out of, or in ambivalent relation to, the dominant moral order." 33 This fragmentation of shared meaning might even be why modern societies have shifted to technical and private penal modes, such as imprisonment, "aimed at containment of deviant groups who are, in all likelihood, beyond real integration." 34 The processes of trial and sentencing might express and preserve the moral order for insiders, but the experience of punishment is likely nothing more than a lesson in exclusion and punitive control for the criminal target. Certainly, there is little evidence that a struggling young person like Ashley Smith was making moral sense of her treatment in state custody, or that state officials would have characterized their work with her in that way.

\section{Part II: The Smith Experience and Sentencing Law and Practice}

I turn now from this theoretical discussion about the aims and functions of punishment to the concrete doctrinal rules that apply to adult sentencing decisions in Canada. The purpose here is to consider how sentencing courts might respond to concerns about prison administration that arise from cases like Ashley Smith. In our system, the central task of a sentencing judge, and the central question on appellate review, is focused on the question of the fitness of the sentence. A fit sanction is defined as one that is responsive to the individual offender 
and the particular circumstances under which the offence was committed. ${ }^{35}$ Judges analyze fitness almost entirely based on the facts that brought the offender before the court: it is largely a backward-looking affair. The idea is to match the particular level of blameworthiness that inheres in an offence to the severity of the sanction. The determination of fitness is, subject to some specific statutory rules, an individualized process that requires the judge to weigh the objectives of sentencing $^{36}$ in a manner that reflects the circumstances of the case. ${ }^{37}$

An early Charter case, R. $v$ Smith, provides authority for the idea that the proportionality of a sanction can be affected by in-prison treatment. Smith was concerned with the meaning of the protection against "cruel and unusual punishment" in section 12, in the context of a Charter challenge to a mandatory length of confinement of seven years for a broadly defined drug trafficking offence. In his majority decision, Justice Lamer said that when analyzing whether a sanction will be grossly disproportionate, courts should consider not only length but also the effect and conditions of a sentence. The court noted that the "effect of the sentence is often a composite of many factors"; that it is "not limited to the quantum or duration of the sentence ... but includes its nature and the conditions under which it is applied." 38 Justice Lamer describes a hypothetical scenario to show how decisions made in the correctional context may combine to create an unacceptably severe sentence: "[57] ... Sometimes by its length alone or by its very nature will the sentence be grossly disproportionate to the purpose sought. Sometimes it will be the result of the combination of factors which, when considered in isolation, would not in and of themselves amount to gross disproportionality. For example, twenty years for a first offence against property would be grossly disproportionate, but so would three months of imprisonment if the prison authorities decide it should be served in solitary confinement...."39

To date, there is no direct authority-beyond this dictum in Smith-for a prisoner to argue that a sentence has become grossly disproportionate because, for example, time in solitary exceeded the dictates of the sanction announced by the sentencing judge. Nor do sentencing judges state, in their reasons for sentence, what is required in terms of prison conditions for particular offenders. Rather, our system tends to allow the institutional logic and preferences of the prison-its pursuit of security and its contemporary devotion to risk management-to govern the use of solitary confinement and other penal measures. Of course, the prisoner might argue that the time in solitary is itself cruel and unusual punishment, but that will be done by pointing to the conditions of the solitary cell without

$35 \quad$ R. $v$ Wust, 2000 SCC 18 at para. 44.

36 These are set out in full in s. 718 of the Criminal Code. (a) to denounce unlawful conduct and the harm done to victims or to the community that is caused by unlawful conduct; (b) to deter the offender and other persons from committing offences; (c) to separate offenders from society, where necessary; (d) to assist in rehabilitating offenders; (e) to provide reparations for harm done to victims or to the community; and (f) to promote a sense of responsibility in offenders, and acknowledgment of the harm done to victims or to the community.

R. v Nasogaluak, 2010 SCC 6 at para. 43.

R. v Smith [1987] 1 SCR 1045 at para. 57.

Ibid. 
reference to the judicially imposed sanction, and the threshold for proving such claims is high. ${ }^{40}$

The relationship between prison conditions and sentencing also appeared as a topic in the 1999 Supreme Court decision of $R v$ Gladue. Here the court interpreted section $718.2(\mathrm{e})$ of the Code to mean that sentencing judges should consider the unique circumstances of indigenous people at sentencing. ${ }^{41}$ Trial judges were directed to specifically contemplate a non-custodial sanction for indigenous offenders, given historic and present-day systemic discrimination and disproportionally high rates of incarceration. The idea was not that indigenous people should be given a sentencing discount on account of race. Rather, the idea was that the wider historical and social record was relevant to the task of imposing a fit sentence. Like all others, indigenous defendants deserve a proportionate sentence-nothing less but also nothing more. Gladue holds that wider historical and social facts are relevant to the culpability dimension of the proportionality analysis in the case of indigenous defendants.

Gladue is largely focused on whether a shorter or non-custodial sentence should be imposed on some indigenous offenders. But Gladue also directs sentencing judges to consider "the types of sentencing procedures and sanctions which may be appropriate in the circumstances for the offender because of his or her particular aboriginal heritage or connection." 42 The idea here is at least partly that a prison sentence may be a culturally inappropriate mode of sanction. In this way, the court is attentive to the prospective experience of confinement. But Gladue leaves behind many questions as to how specific features of the prison experience should bear upon sentencing, particularly for those indigenous defendants who do receive a custodial sanction.

The earlier Smith decision suggests that a sentence may become disproportionate in the course of its administration. This means not only that prison conditions are relevant to sentencing, but also that the declaration of sentence should not mark the end of judicial concern with it. If Lamer J.s suggestion was an accurate reflection of our legal system today, those advocates attempting to protect Ashley Smith before her death may have had a legal basis to take different steps on her behalf. Today, our legal system plainly lacks a real commitment to that view. The Smith case throws up some flares in the early days of the Charter, but the flares are not widely seen.

Typically, the imposition of a prison sentence follows a highly formal process in which a court purports to decide severity by imposing a sentence length that is meant to be commensurate with the facts that brought the offender before the court. Scholars are beginning to map exceptions, however, such as Benjamin Berger who points to places where the Supreme Court of Canada has called on judges to think about sentencing in ways "better attuned to the lived experience

40 The "cruel and unusual" threshold in section 12 of the Charter is described as treatment grossly disproportionate to what would have been appropriate, or so excessive as to outrage standards of decency. For a rare successful section 12 claim, see Bacon v Surrey Pretrial Services Centre (Warden), 2012 BCSC 1453 at paras. 300-19. For discussion, see Debra Parkes, "The Punishment Agenda in the Courts," 67 Supreme Court Law Review (2d) (2014): 589-615.

$41 \quad R v$ Gladue, [1999] 1 SCR 688.

42 Ibid. 
of punishment." ${ }^{\prime 3}$ It is not difficult to see how the formal commitments to fitness and parity at the centre of our system can be defeated by the dynamics of the postsentencing context.

Two categories of sentencing cases that are sensitive to this tension emerge. First, there are vulnerable defendant cases, in which judges respond to concerns about the effects of imprisonment on those with particular needs. Second, there are place of imprisonment cases, in which judges consider the quality of jail or prison programming when deciding, for example, between a provincial or federal institution, provided that they act on the basis of a sufficient evidentiary record. Taken together, these cases suggest that sentencing courts do have authority-and have exercised such authority in a limited set of cases-to register their concern about the likely treatment of defendants in custody. Formalizing and extending these approaches could help to better respond to law's commitment to proportionality, particularly when sentencing individuals who present with vulnerabilities to the penal institutional context.

\section{The Vulnerable Defendant}

R. $v$ Adamo was another case about a mandatory minimum sentence. ${ }^{44}$ Adamo was convicted of a series of firearms-related offences that arose as a result of police discovering a handgun and some ammunition inside a garden shed on his property. He was thirty-nine years old, unemployed, and living with his elderly mother. At sentencing, the court considered the fact that Adamo experienced a severe brain trauma in 2000 as a result of being beaten with a baseball bat by two members of the Hells Angels. The injury caused extensive damage to his left temporal lobe and left him significantly impaired in terms of brain function, memory, impulse control, and judgment. He was hospitalized for a lengthy period. The court noted that, for unknown reasons, Adamo was discharged without a complete assessment and without receiving any rehabilitation. ${ }^{45}$

The Adamo court noted that where offenders will be particularly negatively impacted by imprisonment, because of physical or mental disabilities, that might be a mitigating factor. ${ }^{46}$ Adamo also cites multiple authorities for the proposition that the risks of incarceration for certain populations can form the basis for a reduced sentence. In R. $v$ Newby, the Alberta Court of Appeal agreed that the fact that the offender was at risk of committing suicide if incarcerated was an important mitigating factor that contributed to its conclusion that a suspended sentence was in order. ${ }^{47}$ In $R . v$ Wallace, the Court of Appeal reduced a ten-year sentence for armed robbery to four, because the trial judge failed to properly consider information provided by the accused's psychiatrist as to how imprisonment would

43 Discussing cases concerning police misconduct, the collateral consequences of a sentence and delayed parole: Benjamin L. Berger, "Sentencing and the Salience of Pain and Hope," in The Dignity of Law: The Legacy of Justice Louis LeBel, ed. Dwight Newman and Malcolm Thorburn (Toronto, ON: LexisNexis Canada Inc., 2015).

44 R. v Adamo 2013 MBQB 225.

45 Ibid. at para. 9.

46 At para. 48, citing Sentencing, at 231-34.

$47 \quad$ R. $v$ Newby (1991), 1991 ABCA 307. 
be particularly severe for this offender, given his extreme fears of attack or imminent death at the hands of other inmates or staff. ${ }^{48}$ The Wallace court said, "... It is plain that a sentence the length of that imposed was very much more severe punishment for this man [than] for a normal person, because of the terror that he experiences, the danger of self-destruction and the loss of amenability to treatment as well as the fact it is unlikely he can achieve an early release because that treatment which he is in need of must be deferred because of the sentence he must serve." $^{49}$

In many cases, a concern about the impact of imprisonment on a vulnerable defendant will be based on prediction rather than fact. For many defendants, however, there may be relevant evidence from a previous period of incarceration. In Adamo, the court noted evidence from a correctional officer outlining Adamo's difficulties while in pretrial custody:

November 1, 2010 - On arrival to WRC he was assessed as uncooperative, sober.

December 20, 2010 - He was charged for threatening to shoot and kill a CO if he sees him on the outside. He faced an institutional discipline board and pleaded guilty. Awarded ten days punitive segregation and placed on special handling status.

January 8, 2011 - He was involved in a physical altercation with another inmate believed to be a gang member. Was internally relocated as a result.

January 10, 2011 - He was internally relocated due to threatening another inmate, a known gang member.

Now, there is little doubt that institutional officials would characterize these incidents as part of a pattern of institutional misconduct on the part of Adamo. The trial judge, however, interpreted this record differently, observing that these incidents actually illustrate how Adamo's impulsive, easily agitated demeanour, lack of judgment, insight, and self-control, combined with his fixation on gangs, affects his behaviour. And while the sentencing judge noted that a remand facility (where Adamo had been held during these events) is by nature ill-equipped to deal with inmates with special needs, the court also pointed to evidence that "little assistance" would be available to Adamo at Stony Mountain Institution, the only federal penitentiary in Manitoba. ${ }^{50}$

The Crown responded to the court's concerns about federal custody by filing a report authored by project officers with the Correctional Service of Canada. The report suggested that Adamo could access a Supportive Living Range ("SLR") at Stony Mountain Institution, designed for inmates who cannot be housed in general population of "due to their vulnerability to exploitation and manipulation by other inmates, their risk of self-harm and their general inability to function independently." ${ }^{\text {"51 }}$ The report suggested that the SLR aims to maintain and promote

$48 \quad$ R. $v$ Wallace (1973), 11 C.C.C. (2d) 95 (Ont. C.A.).

Wallace at p. 100.

Adamo at para. 53.

Ibid. at para. 54 . 
mental health partly through counselling and a "holistic approach" that stems from "partnership between correctional personnel and mental health professionals." 52

But the court examined the potential adequacy of the SLR program carefully. One expert witness, Dr. Waldman, testified that based on his personal experience in working with inmates at Stony Mountain, he was aware that there are no therapists involved in the SLR. At the conclusion of Dr. Waldman's testimony, the Crown indicated it would be calling rebuttal evidence in response. The next day, however, the Crown indicated that, in fact, after speaking with a representative of Stony Mountain Institution, there was no issue to take with Dr. Waldman's evidence. Nevertheless, the Crown argued in its submissions that a term of imprisonment in excess of the mandatory minimum should be applied, and that his "mental health needs will be the responsibility of Corrections Canada." 53

Justice Suche rejected this plea for deference from a correctional system that could not furnish an acceptable assurance about treatment. She declared the three-year mandatory term unconstitutional and imposed six months' imprisonment, the entirety of which had been served during the time Adamo was held in pre-trial custody. Justice Suche rested her decision largely on various mitigating issues connected to Adamo's mental capacity and the treatment he had received at the hands of the state in connection with that condition. Regarding imprisonment itself, the court said the following:

It is also safe to say that imprisonment would be much harsher punishment for Mr. Adamo than for others. As demonstrated by his time in the Winnipeg Remand Centre, his tendency to misinterpret his environment, his underlying anxiety and fear about gangs, and lack of impulse control and insight put him at risk. No doubt he is his own worst enemy. While his condition today is much better than it was then as a result of being treated, nonetheless, he still suffers from the same deficits. Compounding the situation, of course, is the fact that the programming he requires would not be available in federal penitentiary. ${ }^{54}$

While only a trial level authority in Manitoba, the Adamo decision is remarkable for its attention to the particular traits of a defendant and the question of how these traits would interact with the features of closed confinement. While the Crown attempted to assure the trial court that Adamo's correctional programming would contain appropriate supports and treatment, the judge opted not to take those assurances at face value. ${ }^{55}$ The following cases explore the question of the evidentiary basis that judges should have before making such decisions, while clearly affirming that prospective issues of sentence administration can form a proper part of the search for a fit sentence.

Ibid. at para. 54 .

Adamo at para. 60 .

Adamo.

In doing so, the court declined to follow more deferential approaches such as that in $R$. $v$ Shahnawaz (2000), 149 C.C.C. (3d) 97 (OCA), which accepted that the mental health needs of a defendant suffering post-traumatic stress disorder would be the responsibility of corrections authorities. See also R. v Peterkin, [2003] O.J. No. 4403 (Ont SCJ), observing that correctional authorities are obliged under the Corrections and Conditional Release Act to provide essential healthcare. The Adamo decision is striking in light of these authorities that accept the presence of a legislative duty as a satisfactory indication that it will be fulfilled. 


\section{Place of Imprisonment}

The following cases concern the judicial power to select a particular sentence length so as to achieve either a federal or a provincial sentence. In each case, the key issue was the evidentiary basis for the judicial choice. Courts that operated on the basis of background knowledge about particular facilities, rather than facts adduced on the record, were at risk of committing an error in principle and being overturned.

R. $v$ Boucher ${ }^{56}$ involved an attempted murder committed in a domestic context. The victim suffered no injuries, though the defendant had the specific intent to kill and used his vehicle to hit his estranged wife's vehicle. The Crown argued for a sentence in the range of eight years to life imprisonment. The sentencing judge indicated his concern that, even with a long sentence in the range suggested by the Crown, the accused would be released before the conclusion of his sentence and without having received any treatment for his underlying delusion that his estranged wife would reconcile with him. In addition to fourteen months of credit for pre-trial time, the judge imposed a sentence of two years less a day plus two years of probation.

The Ontario Court of Appeal found the sentence to be unfit, largely because the trial judge failed to emphasize the aggravating factor of the planned and persistent nature of the defendant's conduct. Most notable for my concerns here, the court held that the trial judge erred in concluding that the defendant was more likely to receive treatment and remain subject to appropriate controls if sentenced to the provincial correctional system rather than to the federal penitentiary system. ${ }^{57}$ The problem was a lack of evidence. Specifically, there was no evidence before the trial judge concerning "the relative likelihood" of receiving counselling in either system, nor was there evidence as to what conditions might be imposed if and when he was released on parole. ${ }^{58}$ The court continued, "Although it may be appropriate in some cases to depart from a sentencing range to ensure that a convicted person will receive specific treatment that has been prearranged, such a departure is not appropriate where it is unclear that particular treatment will be provided and where there is no evidence concerning the treatment and supervision that would be available if a sentence in the appropriate range was imposed." ${ }^{39}$

The problem in Boucher was not that the trial judge used treatment prospects as a reason to depart from a sentencing range, but that the judge did so without a sufficient evidentiary record. Similarly, in R. v J.K.F. ${ }^{60}$ the Ontario Court of Appeal heard an appeal of a sentence of nine months and two years' probation for sexual assault. The trial judge exceeded the term suggested by the Crown, because he wanted the accused to obtain treatment at the Ontario Correctional Institute and he believed that a sentence of nine months was required to obtain it. The Court of Appeal found that there was no evidence as to whether treatment was available at

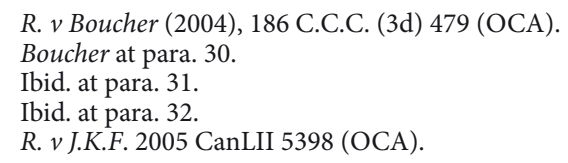


this facility, and if it was, how long a sentence was required to provide effective treatment. Exceeding the range suggested by the Crown "without an adequate evidential foundation" constituted an "error in principle." sentence to four months, in addition to the probation.

Finally, in R. $v$ Snelgrove, ${ }^{62}$ a trial judge appears to make a similar error: imposing a particular sentence on the basis of a presumption about programming. The judge imposed a penitentiary term for offences of forcible confinement (two and half years) and assault with a weapon (one year concurrent), committed in the context of substance abuse. The trial judge selected these terms in part because he thought the accused would be able to attend a high-intensity drug treatment program. The defendant appealed partly on the basis that the sentence on the confinement count was excessive and unfit. On appeal, the court was influenced by the fact that the high-intensity drug treatment was not in fact available. The court concludes that the "hopes and expectations of the learned trial judge have not been realized and apparently are not going to be fully realized having regard to the resources of the institution." ${ }^{\prime 3}$ The court reduced the sentence to eighteen months and added probation with specific treatment terms. ${ }^{64}$

Unlike Boucher and JFK, the appellate court in Snelgrove does not criticize the trial judge for lacking evidence about the prospects of accessing a specific drug treatment program. Rather, it was simply that the course of treatment that the trial judge had in mind "has proved to be an impossible achievement." ${ }^{65}$ The case confirms, like Boucher and JFK, that post-sentencing issues are an appropriate part of the factual matrix that a court can draw from in articulating a fit sentence. While making clear that both counsel and judges must ensure a proper evidentiary foundation to ground their approach, these developments hold clear promise for improving the responsiveness of sentencing to the treatment of vulnerable defendants.

\section{Conclusion}

The decisions of sentencing courts are inevitably under-specific. A judge assesses the level of blameworthiness that inheres in a particular offence and a particular offender, and purports to link those findings to a particular type of sanction. Where the judge decides on a sanction of imprisonment, the court purports to settle severity by stipulating a particular length of time. In this article, I drew from Ashley Smith's experience in adult custody in order to raise a challenge to this formalized portrait of criminal sentencing. The lived experience and fatal consequences of imprisonment for Smith resulted not from any judicial decision, but from the policies and decisions of prison officials, combined with the physical and legal infrastructure of the prison system. The question that arises is whether and how sentencing courts might respond to these institutional dynamics from within the frame of their sentencing authority.

\section{Ibid. at para. 3 .}

R. v Snelgrove 2005 BCCA 51.

Snelgrove at para. 10.

Ibid. at para. 13 .

Ibid. at para. 13 . 
Sentencing courts rely on a number of penal theories that are thought to both constrain and legitimize our system of sentencing and imprisonment. The principles of proportionality, denunciation, and just deserts are among the legislatively established aims of sentencing in our Criminal Code. Judges draw from these concepts to make decisions in particular cases, and scholars debate the various elements of the theories. But we tend not to consider whether and how these principles square with the institutional reality of sentence administration.

Rather than communicating moral messages to inmates à la Duff, those charged with administering closed custodial facilities are primarily focused on secure operations. And while a court's announcement of a punishment may have an educative function that serves to consolidate social solidarity in the way Durkheim describes, the carrying out of that punishment occurs amid the far more complex and ambivalent moral order of the jail or penitentiary. We might use these insights to temper our confidence that custodial sentences are justified according to one or another of these philosophical or explanatory frames. The fact is that our standard theories of punishment cover very little ground.

Occasionally, sentencing courts feel the pressure of the questions that the death of Ashley Smith brought to the national stage: about the quality of our prison system, the conduct of correctional officers and managers, and the effects of confinement on vulnerable populations. To date, this has largely occurred in cases of defendants who present as particularly vulnerable to the prison context at sentencing, or where a concern arises about the need for a defendant to access a particular program or treatment.

The Adamo decision is about the meaning of proportionality given prison conditions. Justice Suche was concerned with how confinement can become grossly disproportionate to culpability when one factors in the qualitative experience of imprisonment. In this way, the decision echoes the observations of Justice Lamer from over twenty-five years earlier in Smith, who said that the "effect of the sentence is often a composite of many factors..."; it is "not limited to the quantum or duration of the sentence... but includes its nature and the conditions under which it is applied." ${ }^{66}$ To date, that common sense notion has played little role in our sentencing jurisprudence, but it fits easily enough with the wide-ranging discretion of trial judges to weigh multiple factors in the search for a fit sentence.

There are, of course, a number of evidentiary issues associated with asking courts to make decisions based on issues that will emerge after the court's decision, as the place of imprisonment cases make clear. The administration of a sentence inevitably occurs after it is announced, in a venue that is not the domain of the judiciary. But there is nothing unusual about asking a court to decide a legal issue on the basis of a prediction, and on the basis of evidence adduced from those with appropriate expertise. To take just one example, the calculation of damages for personal injuries is often concerned with future categories of loss. The question is always one of establishing a sensible evidentiary basis for a decision. 
At times, trial judges have issued sentencing decisions based on their own background knowledge of particular facilities. That knowledge may be untested, outdated, or too thin. Recall how the New Brunswick youth court that transferred Ashley Smith to adult custody heard speculative evidence about the enhanced programs that would be available to her there. To borrow from the language of the reviewing court in Snelgrove, the "hopes and expectations" of the judge were not realized. No adjustment was made to the sentence of Ashley Smith, but Snelgrove indicates that where a sentencing judge relies without adequate foundation on claims of in-prison program access, the resulting decision may be overturned on appeal. Sentencing should be a search for a fit sanction in both length and form, and the difficulties of prison reform should compel us to seek a sentencing jurisprudence that is responsive to our institutions of punishment.

Lisa Kerr

Assistant Professor

Faculty of Law, Queen's University

lisa.kerr@queensu.edu 